« Majmū'e-ye tārīHīi-ye ŠeyḤ Ṣafī al-Dīn Ardabīlī. Hāstgāh-e tašayyo'-ye farāgīr / The Historical Monument of Sheikh Safiyeddin Ardebili; The Origin of General Shiism ». Majmū'e maqālāt-e motāale āt-e ìrānī / An Anthology of Iranian Studies, 8, 1384/2005, pp. 123-151 (texte persan) et pp. 215-228 (traduction anglaise par Homā Lezgi).

\title{
Maria Szuppe
}

\section{OpenEdition}

Journals

Édition électronique

URL : http://journals.openedition.org/abstractairanica/11562

DOI : 10.4000/abstractairanica. 11562

ISSN : 1961-960X

Éditeur :

CNRS (UMR 7528 Mondes iraniens et indiens), Éditions de l'IFRI

Édition imprimée

Date de publication : 15 mai 2007

ISSN : 0240-8910

Référence électronique

Maria Szuppe, « « Majmū̄e-ye tārīhīi-ye Šeyḩ Șafī al-Dīn Ardabīì. Hāastgāh-e tašayyo'-ye farāgīr / The Historical Monument of Sheikh Safiyeddin Ardebili; The Origin of General Shiism ». Majmū'e maqālāt-e moțāle'ât-e îrānī / An Anthology of Iranian Studies, 8, 1384/2005, pp. 123-151 (texte persan) et pp. 215-228 (traduction anglaise par Homā Lezgi). », Abstracta Iranica [En ligne], Volume 28 | 2007, document 231, mis en ligne le 18 septembre 2007, consulté le 25 septembre 2020. URL : http:// journals.openedition.org/abstractairanica/11562 ; DOI : https://doi.org/10.4000/abstractairanica. 11562

Ce document a été généré automatiquement le 25 septembre 2020. 
« Majmū'e-ye tārīH̄ī-ye ŠeyH Șafī alDīn Ardabīlī. Hāāstgāh-e tašayyo'ye farāgīr / The Historical Monument of Sheikh Safiyeddin Ardebili; The Origin of General Shiism ». Majmū'e maqālāt-e moțāle‘ āt-e ìrānī / An Anthology of Iranian Studies, 8, 1384/2005, pp. 123-151 (texte persan) et pp. 215-228 (traduction anglaise par Homā Lezgi).

Maria Szuppe

À l'occasion de la destruction d'un mur dans le cadre de travaux urbains de routine menés à l'intérieur de l'ensemble architectural du mausolée de ŠeyH Șafī al-Dīn (m.1334) à Ardabîl (toujours en activité), plusieurs niveaux anciens, jusqu'à là insoupçonnés, ont été découverts. Le présent article résume les travaux archéologiques et études architecturales qui ont été conduits sur une partie du site pendant cinq saisons (localisation des chantiers, p. 262, et p. 216-217), et ont abouti à la mise au jour de plusieurs constructions allant du VIII $/ \mathrm{XIV}^{\mathrm{e}} \mathrm{s}$. à l'époque qajare. L'A. présente trois découvertes : 1 . une partie du mur principal de la «nouvelle » čelle-Hुāne (que l'A. date $\mathrm{du} \mathrm{VIII}^{\mathrm{e}} / \mathrm{XIV}^{\mathrm{e}} \mathrm{s}$.) ; 2. le Hुāneqāh composé de trois pièces principales et d'autres espaces plus petites (datés par la céramique des $\mathrm{VII}^{\mathrm{e}}-\mathrm{IX}^{\mathrm{e}} / \mathrm{XII}^{\mathrm{e}}-\mathrm{XV}^{\mathrm{e}} \mathrm{s}$.) ; 3. le " haštī » dont la fonction ancienne n'est pas claire, mais il s'agit peut-être du tout premier Hुāneqāh de 
ŠeyH Șafì (?). La présentation de ce matériel est accompagnée par la lecture des sources historiques qui mentionnent ou décrivent l'ensemble architectural d'Ardabill. L'A. argumente pour la révision de certains points de chronologie de ce complexe architectural, telle qu'elle avait été adoptée suite au travail fondamental d'A. H. Morton (Iran XII, 1974, et Iran XIII, 1975), en fonction de ces nouvelles données archéologiques.

2 Sur trois photographies présentées, une seule a un rapport direct avec le sujet de l'article (p. 266, et p. 220 : elle montre le mur en brique de la pièce A du Huāneqāh). Des plans et dessins auraient été fort utiles pour visualiser, par exemple, la disposition des bâtiments fouillés.

INDEX

Thèmes : 5.1. Monde iranophone

\section{AUTEURS}

MARIA SZUPPE

CNRS / Mondes iranien et indien - Paris 